\title{
Paying for nature: what every conservationist should know about political economy
}

IVAN R. SCALES

\begin{abstract}
Global conservation policy and global capitalism have become increasingly intertwined over the last decade. The move towards 'green capitalism' has manifested itself in diverse ways, most notably in the expansion of payments for environmental services and attempts to commodify nature. However, there are concerns that prioritizing the financial value of nature could undermine efforts to conserve biodiversity. One particularly strong set of critiques has emerged from political economy. While providing rich theoretical and empirical insights into the potential downsides of green capitalism, the literature is often dense and difficult for non-specialists to navigate. Here I review and translate its main concepts and critiques for a conservation audience. I begin by exploring the basic process of commodity exchange. I then consider nature as a reluctant and uncooperative commodity that often requires new institutions and technologies to be commodified. This means conservation organizations play a key role in green capitalism's political economy. These developments are likely to have considerable social and environmental impacts, with a highly uneven distribution of costs and benefits.
\end{abstract}

Keywords Environmental values, green capitalism, market environmentalism, neoliberal conservation, payments for environmental services

\section{Introduction}

T $\mathrm{n}$ an effort to address conflicts between economic growth 1 and the maintenance of biological diversity, global conservation policy and global capitalism have become increasingly intertwined over the last decade. The idea that capitalism can and should help conservation is now mainstream (Brockington \& Duffy, 2010). This trend has manifested itself in diverse ways, including partnerships between conservation non-governmental organizations (NGOs) and large corporations to help reduce and offset the environmental impacts of their activities (Burgin, 2008; Seagle, 2012), conservation NGOs playing a key role in the

Ivan R. SCALES St Catharine's College, University of Cambridge, Trumpington Street, Cambridge, CB2 1RL, UK. E-mail irs28@cam.ac.uk

Received 29 August 2013. Revision requested 8 October 2013. Accepted 7 January 2014. First published online 29 April 2014. expansion of payments for environmental services such as carbon sequestration (McGregor, 2010; Fisher, 2012), and NGOs promoting and managing ecotourism as a way of generating funds for conservation (West \& Carrier, 2004; Duffy, 2006).

These developments can be seen as part of a broader trend of trying to 'green' capitalism (Prudham, 2009; Igoe et al., 2010). Green capitalism is based on the belief that environmental degradation is largely the result of the failure of markets to reflect the environmental costs of production and consumption and the value of natural capital. Following on from this, private property and the assignment of economic values to the environment are seen as the best way to manage natural resources (Anderson \& Leal, 2001; Farber et al., 2002). Green capitalist policies are presented as win-win solutions, with the potential to create opportunities for economic growth, incentives for the maintenance of biological diversity, and financial support for conservation activities (Ferraro, 2011). Placing an emphasis on the economic value of nature is often put forward as the only realistic and pragmatic way of explaining the importance of conservation to policy-makers and business leaders and achieving conservation goals (Igoe et al., 2010).

The implicit assumption behind capitalism generally, and green capitalism more specifically, is that it is the system best suited to the real world of scarce natural resources and unlimited human wants (Gowdy et al., 2010). This argument is based on the presumption that only through pricing will people understand the value of nature and therefore act responsibly (Roberts, 2008). These ideas have resulted in growing efforts to commodify nature (Igoe et al., 2010; Fairhead et al., 2012).

The increasingly close relationship between conservation and capitalism has led to growing concerns among some conservationists that conservation is selling out on nature (McCauley, 2006). There are worries that important intrinsic and cultural dimensions of nature are being lost in the rush for utilitarian economic solutions (Collar, 2003; Pyle, 2003; Clements et al., 2010). Although important, these arguments have been well rehearsed. My aim here is to show there are more radical critiques that conservation researchers and practitioners should be aware of, and to make them accessible to a conservation audience. I do so in response to calls for conservation research and practice to be more interdisciplinary, as well as to comments that differences in language and concepts often make this 
difficult (Campbell, 2005; Balmford \& Cowling, 2006; Fox et al., 2006). With this in mind, I review and translate recent research by scholars in the social sciences on the political economy of conservation. Broadly speaking, political economy pays close attention to the role of political institutions and power in economic systems (Johnston et al., 2001). The fundamental questions of political economy are: (1) who does what in an economic system, (2) who owns what, (3) who gets what, and (4) what do they do with it (Bernstein, 2010)?

Given the volume and theoretical complexity of the literature, I concentrate on a small number of core concepts, mainly from Marxian political economy, as well as specific case study examples, primarily from low-income nations. I begin by exploring the basic process of commodity exchange under capitalism. I then consider nature as a reluctant and uncooperative commodity that often requires new institutions and technologies to be commodified. This means conservation organizations play a crucial role in the commodification of nature and have moved from the critical margins of global capitalism to playing a key role in green capitalism's political economy. These developments are likely to have significant social and environmental consequences, with a highly uneven distribution of costs and benefits.

\section{Capitalism and commodities}

At its most basic, capitalism can be described as a system for organizing production (a 'mode of production' in Marxian terminology) based on private ownership, the exchange and distribution of goods and services through markets, and driven by the profit motive (Bowles, 2007). It is a distinct and increasingly pervasive way of 'making, moving and selling all manner of goods and services' (Castree, 2003, p. 274). As a mode of production it places considerable emphasis on commodities.

A commodity can be defined as something that is produced for the purpose of exchange (Kosoy \& Corbera, 2010). So when conservation policy attempts to place an economic value on the environmental services provided by nature and promotes or facilitates the exchange of these services for money, it can be said to be commodifying nature. In other words, commodification is the 'process whereby goods formerly outside marketised spheres of existence enter the world of money' (Bakker, 2005, p. 545). The concept of a commodity has a central role in political economy, since it plays a crucial part in shaping social relations and the relationship between humans and the material world around them.

The simplest form of commodity exchange involves bartering. We can represent this form of exchange as Commodity to Commodity, or C-C. The point is that commodities are exchanged because of their use values. As well as bartering, money can be used as a form of mobile value. This commodity exchange can be represented as Commodity-Money-Commodity, or C-M-C. This allows a commodity to be exchanged for money in one place, the value stored or moved and then exchanged for another commodity. The important point is that this doesn't necessarily change the purpose of the exchange, which emphasizes the use value of that commodity.

There is considerable variation between societies (historically and geographically) in what is considered to be private property and what is exchanged as commodities (Bowles, 2007). Under certain modes of production commodities become a vehicle for profit and capital accumulation; i.e. money is invested for the sole purpose of making profit. This form of exchange is represented as $\mathrm{M}-\mathrm{C}-\mathrm{M}$. The emphasis here is not on what the commodity can be used for but what it can be exchanged for: its exchange value is prioritized over its use value. While capitalism is by no means the only mode of production that involves transactions based on exchange value, it makes it a core principle. Capitalism is driven by competition, wealth accumulation and an increase in the productive and consumptive capacity of society. The logic of capitalism thus dictates that capital continually searches for investment opportunities and sources of continued economic growth; i.e. new profitability frontiers. Because capitalism needs new profitability frontiers, it must always be in search of new objects and processes to commodify (Harvey, 2005). The relentless quest for growth and profits has thus seen an ever greater number and range of objects, assets and processes come under private ownership and market exchange (Watts, 1994; Harvey, 2003).

The most recent phase of global capitalism, emerging in the late 1970s, is described as 'neoliberal'. Broadly speaking, neoliberalism can be described as a set of policy measures informed by a distinct world-view that places emphasis on individual liberty and freedom, minimal involvement of the state, and free markets as the best way to coordinate the diverse needs of people (Castree, 2003, 2010; Harvey, 2005; Igoe et al., 2010; Peck, 2010). In terms of policy, neoliberalism tends to promote the privatization of state assets and common pool resources, clear property rights, and the deregulation of markets to allow maximum entrepreneurial freedom (Harvey, 2005; Castree, 2008; Peck, 2010). Under green capitalism, previously uncommodified aspects of the natural world are becoming part of capitalism's profitability frontier. This is interpreted by some scholars as the neoliberalization of conservation (Igoe et al., 2010; Fletcher, 2012). The important question is how the greater commodification of nature under green capitalism might alter social and environmental relations. From the perspective of political economy the answer to this question depends on how nature behaves as a commodity. 


\section{Nature as a reluctant and uncooperative commodity}

The problem with treating nature as a commodity is that it is not produced specifically for the purpose of exchange. Like land and labour, nature is a fictitious commodity (Polanyi, 1944) and must be commodified through the creation of new institutions and technologies (Harvey, 2005). However, nature can be a reluctant commodity and hard to commodify. The neoclassical economic definition of a commodity is based on the idea of a standardized good or service, with interchangeable units and a price determined through market exchange (Bakker, 2005). A good commodity (i.e. something that is straightforward to exchange) has clear values, boundaries and property rights (Kosoy \& Corbera, 2010). This is the opposite of most ecosystems and landscapes: their values are multiple, complicated and differ between people and cultures, with often unclear and contested ownership rights (Bakker, 2005; Carrier, 2010; Castree, 2010).

Bakker's (2005) research on the privatization of water supply and management in England and Wales shows just how uncooperative nature can be as a commodity. Water is difficult to own, manage privately and commodify. Firstly, its provision and use involves a set of complex and diffuse biophysical processes: from precipitation to surface flow, river flow and storage. Secondly, its provision is dependent on major infrastructure that requires considerable investment and therefore favours monopoly control rather than competing providers in a free market. Thirdly, flows of water cut across political and economic boundaries at various spatial levels, leading to complex politics of ownership and control. Finally, water involves a diverse set of users with different and sometimes conflicting priorities. Its privatization and commodification has thus been both partial (i.e. only part of the process can be privatized and commodified) and highly contested (Castree, 2003; Bakker, 2005; Roberts, 2008). As I discuss in the next section, these factors have often led to an uneven distribution of costs and benefits.

Because ecosystems and the services they provide are complex, most conservation policy efforts to commodify nature tend to focus on one or two specific services and also simplify those services as much as possible. Looking at carbon offsets for example, for the sake of simplicity and efficacy, schemes tend to treat carbon as fungible; i.e. different forms of carbon, locked up in different forms of biomass and released through diverse processes, become mutually substitutable. Carbon is thus converted into a uniform commodity and separated from both its social and ecological context so that it can be traded on global carbon markets (van der Horst \& Evans, 2010; Bumpus \& Liverman, 2011). This is likely to lead to a narrowing of vision when it comes to environmental policy, so that other values and issues are crowded out.
In the context of climate change, the world's forests are increasingly seen through the lens of carbon sequestration. The current priority is to reduce carbon in the atmosphere, through whatever means: renewable energy, energy efficiency or carbon offsets. Offsetting carbon by paying low-income nations to maintain tropical forest cover through avoided deforestation is seen as a cheap way of doing this (Kindermann et al., 2008; Bumpus \& Liverman, 2011). However, in privileging carbon, other social and environmental concerns risk being forgotten. The focus on carbon has already led to the planting of certain tree species over others because of their high carbon content and rapid growth rates, and could encourage investment in plantations instead of work on restoring complex ecosystems or maintaining biodiversity (Kosoy \& Corbera, 2010).

\section{The power relations behind the commodification of nature}

Given the fact that nature is often an uncooperative commodity, the process by which it is commodified, and its power relations, deserve special attention. Dealing first with the question of 'who does what' (Bernstein, 2010) in a green capitalist mode of production, the commodification of environmental services is based on its own distinctive division of labour and elites. Given their largely fictitious character, the commodities traded under green capitalism rely on particular individuals and institutions to create and maintain them. They also require new ways to quantify and measure the services provided. Looking at regulating services such as carbon sequestration for example, these require complex scientific measurements and financial mechanisms (Kosoy \& Corbera, 2010). The elites in this mode of production are the scientists who facilitate the measurements of carbon, the consultants and organizations who advise on carbon-offset projects, and the financial experts and institutions who sell credits on carbon markets (Bumpus \& Liverman, 2008, 2011). Looking at biodiversity offsets, these also depend on the scientific and policy mechanisms and institutions that measure and prioritize biological diversity (MacDonald \& Corson, 2012). The result is likely to be unequal bargaining power between the various actors (buyers, sellers and intermediaries), with global buyers benefiting from greater experience, knowledge and buying power (Karsenty, 2007; Bumpus \& Liverman, 2008).

Conservation NGOs play a key role in the commodification of nature. They have positioned themselves as gatekeepers between capital and nature and have sought to increase their influence by providing authoritative knowledge on ecosystem function and management (MacDonald, 2010). Conservation organizations and the environmental movement more generally have thus moved from being 
critical voices on the margins of capitalism to playing a central role in creating new profitability frontiers and enabling capital to expand into new areas (Fairhead et al., 2012). In Madagascar, for example, a group of conservation NGOs has formed a partnership with Rio Tinto/QMM, providing advice on the environmental impacts of ilmenite mining and helping to negotiate biodiversity offsetting, receiving funding for conservation activities in the process (Seagle, 2012).

Dealing with questions of ownership and distribution (i.e. who owns what, who gets what, and what do they do with it; Bernstein, 2010) there is concern that the commodification of nature will result in an uneven distribution of costs and benefits, with some even losing access to natural resources. Research on the commodification of water has shown what can happen when economic efficiency is prioritized over social and environmental equity. While in many cases the privatization of water has resulted in an overall improvement in water supply, this is usually accompanied by a large increase in costs for consumers (Bakker, 2005; Roberts, 2008). This can have serious socio-environmental impacts. In South Africa privatization led to significant price hikes and resulted in poor households being disconnected from the water supply between 1994 and 2002 (Bond, 2004). In KwazuluNatal this forced the poorest residents to access water from a polluted river, leading to a cholera outbreak that killed hundreds and infected thousands more (Bond, 2004; Roberts, 2008).

Critics of green capitalism see a strong potential for socalled green grabbing: the appropriation of land and natural resources by elites both for environmental ends and to allow further accumulation of wealth (Bumpus \& Liverman, 2008; Fairhead et al., 2012). It is likely that in low-income nations, in particular, the potential wealth to be gained from commodified environmental services will lead to a strong incentive for elites (local, national and international) to take control of natural resources (Sandbrook et al., 2010). Green grabs could thus mirror the spate of recent agricultural land grabs, which have seen a range of corporate and state interests securing access to land for the cultivation of food crops and biofuels, dispossessing rural households in the process (Cotula \& Vermeulen, 2009; Demirbas, 2009; White et al., 2012). Green grabs have already been documented in a number of different contexts and geographical locations. In Tanzania and Colombia the desire to secure the cultural environmental services that bring western ecotourists has led to the enclosure of land and the redefinition of rights to use natural resources, with communities excluded from their previous livelihood activities (Benjaminsen \& Bryceson, 2012; Ojeda, 2012). In Madagascar protected areas have been expanded to accommodate biodiversity offsets related to mining operations, limiting local access to forests (Seagle, 2012). In Uganda, households have lost access to land acquired by a Norwegian company for carbon forestry (Nel \& Hill, 2013).

Dispossession doesn't necessarily have to include outright land grabs and the alienation of existing claimants, but may also occur through the restructuring of rules that govern access to and use of natural resources (Fairhead et al., 2012). In the State of Chiapas in Mexico there is evidence that smallholder farms are changing land-use strategies and planting carbon sequestering trees as a new source of income (Osborne, 2011). While in this case tree planting has helped many households to secure land rights and generated alternative sources of income, there have been important differences in the distribution of costs and benefits between and within households. To benefit from carbon offset payments, households have had to shift from short-term food production (for subsistence and cash) to managing longer-term forestry-based income. However, poorer households have been unable to give up short-term food supply and many have complained about the insufficiency of carbon payments in relation to the considerable labour requirements. In some cases, the shift in balance away from short-term food supply has resulted in tensions within households (largely between men and women) about livelihood priorities (Osborne, 2011).

Such arguments have been made before in relation to community-based conservation (Hulme \& Murphree, 2001). Although some households may benefit from new sources of income (especially those that can afford to abandon short-term subsistence activities), poorer households are often the most directly dependent on access to natural resources such as forests and thus stand to lose the most from any schemes that redefine resource use and prioritize environmental services over other livelihood options. It is likely that many attempts to commodify environmental services will keep some individuals, households and communities in poverty traps as they are forced to forgo more lucrative activities in order to protect environmental services (Karsenty, 2007). These previous experiences together with more recent case studies should serve as a reminder of the complex multi-scalar political economy of green capitalism. They suggest that winners and losers are likely to be at multiple spatial levels, with uneven outcomes within households, between households, between communities, up to the international level.

\section{Conclusion}

Green capitalism is increasingly seen by many as the only realistic way of achieving conservation goals. The expansion of green capitalism has seen a proliferation of attempts to commodify nature. For scholars drawing on political economy, this is part of a long historical process of capitalist expansion and the search for new profitability frontiers. 
This has often been achieved by moving assets from the public domain to the private sphere, a process that Harvey (2005) labeled 'accumulation by dispossession'. However, green capitalism differs in important ways from previous waves of capitalist expansion.

The first significant difference is in the types of objects and processes being commodified. The greening of capitalism involves commodifying aspects of nature that have never previously been commodities, for example carbon sequestration and other ecosystem functions. The second difference is in the diversity of actors and the role played by conservation organizations. Whereas in previous forms of commodity expansion conservation NGOs were absent or only on the periphery, and often critiqued business practices and relentless economic growth, many have moved closer to those at the heart of the process (Fletcher, 2012). Conservation NGOs are acting as mediators, facilitators and expert consultants in the commodification of nature (Bumpus \& Liverman, 2008; Brockington \& Scholfield, 2010; Fairhead et al., 2012). Finally, green capitalism differs in the speed of change. The last decade has seen an expansion in the aspects of social and natural life that are treated as commodities. As Karl Polanyi (1944) argued, it isn't just the direction and extent of social change that is important but the rate of change, since it influences whether and how societies can adapt or push back against such changes. Green capitalism proposes significant and rapid changes in the relationship between society and nature, seeking to mediate it principally through commodity exchange and market forces. The danger is that in the rush to commodify nature, conservation serves the interests of capital, rather than markets serving the interests of biodiversity conservation. Perhaps it is time to slow down and start asking questions.

The differences in the types of objects and processes being commodified, the role of the various actors involved and the speed of change under green capitalism ultimately raises questions about the power relations at the heart of green capitalism. Who will be the winners and losers and who will decide? Green capitalism is likely to have its own distinct political economy, with its own divisions of labour and elites, raising questions that need to be addressed urgently. For example, how is property being restructured under green capitalism and to what extent does restructuring lead to dispossession? How are costs and benefits distributed at different points of the commodity chain, between different stakeholders and at different spatial levels? Who exercises power in a green capitalist mode of production and how?

These questions point to a bigger question. As Michael Sandel (2012, p. 10-11) has argued, 'without quite realizing it, without ever deciding to do so, we drifted from having a market economy to being a market society... The great missing debate in contemporary politics is about the role and reach of markets'. Political economy reminds us that particular modes of production are not inevitable. The question shouldn't be whether we can place a financial value on nature, as if there is no other choice. The question is should we?

\section{References}

Anderson, T. \& Leal, D. (2001) Free Market Environmentalism. Palgrave MacMillan, New York, USA.

BAKKER, K. (2005) Neoliberalizing nature? Market environmentalism in water supply in England and Wales. Antipode, 95, 542-565.

Balmford, A. \& Cowling, R.M. (2006) Fusion or failure? The future of conservation biology. Conservation Biology, 20, 692-695.

Benjaminsen, T.A. \& Bryceson, I. (2012) Conservation, green/blue grabbing and accumulation by dispossession in Tanzania. Journal of Peasant Studies, 39, 335-355.

Bernstein, H. (2010) Class Dynamics of Agrarian Change. Kumarian Press, Halifax, USA.

Bond, P. (2004) From racial to class apartheid: South Africa's frustrating decade of freedom. Monthly Review, 55, 45-59.

Bowles, P. (2007) Capitalism. Pearson, Harlow, UK.

Brockington, D. \& Duffy, R. (2010) Capitalism and conservation: the production and reproduction of biodiversity conservation. Antipode, 42, 469-484.

Brockington, D. \& Scholfield, K. (2010) The conservationist mode of production and conservation NGOs in sub-Saharan Africa. Antipode, 42, 551-575.

Bumpus, A.G. \& Liverman, D.M. (2008) Accumulation by decarbonization and the governance of carbon offsets. Economic Geography, 84, 127-155.

Bumpus, A.G. \& Liverman, D.M. (2011) Carbon colonialism? Offsets, greenhouse gas reductions, and sustainable development. In Global Political Ecologies (eds R. Peet, P. Robbins \& M. Watts), pp. 203-224. Routledge, London, UK.

BU RGIN, S. (2008) BioBanking: an environmental scientist's view of the role of biodiversity banking offsets in conservation. Biodiversity and Conservation, 17, 807-816.

CAMPBELL, L.M. (2005) Overcoming obstacles to interdisciplinary research. Conservation Biology, 19, 574-577.

CArrier, J.G. (2010) Protecting the environment the natural way: ethical consumption and commodity fetishism. Antipode, 42, 672-689.

Castree, N. (2003) Commodifying what nature? Progress in Human Geography, 27, 273-297.

Castree, N. (2008) Neoliberalising nature: the logics of deregulation and reregulation. Environment and Planning A, 40, 131-152.

Castree, N. (2010) Neoliberalism and the biophysical environment: a synthesis and evaluation of the research. Environment and Society: Advances in Research, 1, 5-45.

Clements, T., John, A., Nielsen, D., An, D., Tan, S. \& MilnerGulland, E.J. (2010) Payments for biodiversity conservation in the context of weak institutions: comparison of three programs from Cambodia. Ecological Economics, 69, 1283-1291.

Collar, N.J. (2003) Beyond value: biodiversity and the freedom of the mind. Global Ecology and Biogeography, 12, 265-269.

Cotula, L. \& Vermeulen, S. (2009) Deal or no deal: the outlook for agricultural land investment in Africa. International Affairs, 85, 1233-1247.

Demirbas, A. (2009) Political, economic and environmental impacts of biofuels: a review. Applied Energy, 86, 108-117. 
DUfFy, R. (2006) Global environmental governance and the politics of ecotourism in Madagascar. Journal of Ecotourism, 5, 128-144.

Fairhead, J., LeACh, M. \& Scoones, I. (2012) Green grabbing: a new appropriation of nature. Journal of Peasant Studies, 39, 237-261.

Farber, S.C., Costanza, R. \& Wilson, M.A. (2002) Economic and ecological concepts for valuing ecosystem services. Ecological Economics, 41, 375-392.

Ferraro, P.J. (2011) The future of payments for environmental services. Conservation Biology, 25, 1134-1138.

Fisher, J. (2012) No pay, no care? A case study exploring motivations for participation in payments for ecosystem services in Uganda. Oryx, 46, 45-54.

Fletcher, R. (2012) Using the master's tools? Neoliberal conservation and the evasion of inequality. Development and Change, 43, 295-317.

Fox, H.E., Christian, C., Cully Nordby, J., Pergams, O.R.W., Peterson, G.D. \& Pyke, C.R. (2006) Perceived barriers to intergrating social science and conservation. Conservation Biology, $20,1817-1820$.

Gowdy, J., Hall, C., Klitgaard, K. \& Krall, L. (2010) What every conservation biologist should know about economic theory. Conservation Biology, 24, 1440-1447.

Harvey, D. (2003) The New Imperialism. Oxford University Press, Oxford, UK.

Harvey, D. (2005) A Brief Introduction to Neoliberalism. Oxford University Press, Oxford, UK.

Hulme, D. \& Murphree, M. (2001) African Wildlife and Livelihoods: The Promise and Performance of Community Conservation. James Currey, Oxford, UK.

Igoe, J., Neves, K. \& Brockington, D. (2010) A spectacular eco-tour around the historic bloc: theorising the convergence of biodiversity conservation and capitalist expansion. Antipode, 42, 486-512.

Johnston, R.J., Gregory, D., Pratt, G. \& Watts, M. (eds) (2001) The Dictionary of Human Geography. Blackwell Publishing, Oxford, UK.

Karsenty, A. (2007) Questioning rent for development swaps: new market-based instruments for biodiversity acquisition and the land-use issue in tropical countries. International Forestry Review, 9, 503-513.

Kindermann, G., Obersteiner, M., Sohngen, B., Sathaye, J., Andrasko, K., Rametsteiner, E. et al. (2008) Global cost estimates of reducing carbon emissions through avoided deforestation. Proceedings of the National Academy of Sciences of the United States of America, 105, 10302-10307.

Kosoy, N. \& Corbera, E. (2010) Payments for ecosystem services as commodity fetishism. Ecological Economics, 69, 1228-1236.

MacDonald, K.I. (2010) The devil is in the (bio)diversity: private sector "engagement" and the restructuring of biodiversity conservation. Antipode, 42, 513-550.

MacDonald, K.I. \& Corson, C. (2012) 'TEEB Begins Now': a virtual moment in the production of natural capital. Development and Change, 43, 159-184.

MCCauley, D.J. (2006) Selling out on nature. Nature, 443, 27-28.
McGregor, A. (2010) Green and REDD? Towards a political ecology of deforestation in Aceh, Indonesia. Human Geography, 3, 21-34.

NeL, A. \& Hill, D. (2013) Constructing walls of carbon-the complexities of community, carbon sequestration and protected areas in Uganda. Journal of Contemporary African Studies, 31, 421-440.

OJEDA, D. (2012) Green pretexts: ecotourism, neoliberal conservation and land grabbing in Tayrona National Natural Park, Colombia. Journal of Peasant Studies, 39, 357-375.

Osborne, T.M. (2011) Carbon forestry and agrarian change: access and land control in a Mexican rainforest. Journal of Peasant Studies, 38, $859-883$.

PECK, G. (2010) Constructions of Neoliberal Reason. Oxford University Press, Oxford, UK.

PolanyI, K. (1944) The Great Transformation. Rinehart, New York, USA.

Prudham, W.S. (2009) Pimping climate change: Richard Branson, global warming, and the performance of green capitalism. Environment and Planning A, 41, 1594-1613.

Pyle, R.M. (2003) Nature matrix: reconnecting people and nature. Oryx, 37, 206-214.

Roberts, A. (2008) Privatising social reproduction: the primitive accumulation of water in an era of neoliberalism. Antipode, 40, $535-560$.

Sandbrook, C., Nelson, F., Adams, W.M. \& Agrawal, A. (2010) Carbon, forests and the REDD paradox. Oryx, 44, 330-334.

SAndel, M. (2012) What Money Can't Buy: The Moral Limits to Markets. Allan Lane, London, UK.

SEAGLE, C. (2012) Inverting the impacts: mining, conservation and sustainability claims near the Rio Tinto/QMM ilmenite mine in Southeast Madagascar. Journal of Peasant Studies, 39, 447-477.

van der Horst, D. \& Evans, J. (2010) Carbon claims and energy landscapes: exploring the political ecology of biomass. Landscape Research, 35, 173-193.

Watтs, M. (1994) Development II: the privatization of everything. Progress in Human Geography, 18, 371-384.

WEST, P. \& CARRIER, J.G. (2004) Ecotourism and authenticity: getting away from it all? Current Anthropology, 45, 483-498.

White, B., Borras, S.M., Hall, R., Scoones, I. \& Wolford, W. (2012) The new enclosures: critical perspectives on corporate land deals. Journal of Peasant Studies, 39, 619-647.

\section{Biographical sketch}

IVAN SCALES is a geographer specializing in environment and development issues, mostly in sub-Saharan Africa. His research emphasizes the role of political, cultural and economic factors in shaping the way natural resources are used and contested. Current research projects investigate the diversity of environmental values, agriculture and food security, tropical deforestation, and communitybased approaches to conservation. 